\title{
TU/e EN⿴HOUN

\section{The effect of chlorine in the hydrogenation of carbon monoxide to oxygenated products at elevated pressure on Rh and Ir on $\mathrm{SiO} 2$ and $\mathrm{Al} 2 \mathrm{O} 3$}

Citation for published version (APA):

Kip, B. J., Dirne, F. W. A., Grondelle, van, J., \& Prins, R. (1986). The effect of chlorine in the hydrogenation of carbon monoxide to oxygenated products at elevated pressure on $\mathrm{Rh}$ and $\mathrm{Ir}$ on $\mathrm{SiO} 2$ and $\mathrm{Al} 2 \mathrm{O} 3$. Applied Catalysis, 25(1-2), 43-50. https://doi.org/10.1016/S0166-9834\%2800\%2981220-8, https://doi.org/10.1016/S0166-9834(00)81220-8

DOI:

10.1016/S0166-9834\%2800\%2981220-8

$10.1016 / S 0166-9834(00) 81220-8$

Document status and date:

Published: 01/01/1986

Document Version:

Publisher's PDF, also known as Version of Record (includes final page, issue and volume numbers)

Please check the document version of this publication:

- A submitted manuscript is the version of the article upon submission and before peer-review. There can be important differences between the submitted version and the official published version of record. People interested in the research are advised to contact the author for the final version of the publication, or visit the $\mathrm{DOI}$ to the publisher's website.

- The final author version and the galley proof are versions of the publication after peer review.

- The final published version features the final layout of the paper including the volume, issue and page numbers.

Link to publication

\footnotetext{
General rights

- You may freely distribute the URL identifying the publication in the public portal. follow below link for the End User Agreement:

www.tue.nl/taverne

\section{Take down policy}

If you believe that this document breaches copyright please contact us at:

openaccess@tue.nl

providing details and we will investigate your claim.
}

Copyright and moral rights for the publications made accessible in the public portal are retained by the authors and/or other copyright owners and it is a condition of accessing publications that users recognise and abide by the legal requirements associated with these rights.

- Users may download and print one copy of any publication from the public portal for the purpose of private study or research.

- You may not further distribute the material or use it for any profit-making activity or commercial gain

If the publication is distributed under the terms of Article 25fa of the Dutch Copyright Act, indicated by the "Taverne" license above, please 

PRODUCTS AT ELEVATED PRESSURE ON Rh AND Ir ON $\mathrm{SiO}_{2}$ AND $\mathrm{Al}_{2} \mathrm{O}_{3}$

B.J. Kip, F.W.A. Dirne, J. van Grondelle and R. Prins Laboratory for Inorganic Chemistry and Catalysis, Eindhoven University of Technology, P.0. Box 513, 5600 MB Eindhoven, The Netherlands.

\section{ABSTRACT}

The catalytic behaviour of silica- and alumina-supported rhodium and iridium catalysts in synthesis gas reaction at elevated pressures was investigated. Temperature programmed reduction and hydrogen chemisorption measurements were used to characterize the catalysts. Rhodium was more active than iridium and had a better selectivity to higher hydrocarbons and $\mathrm{C}_{2}$-oxygenates. For rhodium on silica high oxo-selectivities were obtained $(40 \%)$, while on chlorine containing alumina this selectivity was rather low. When a chlorine-free metal precursor was used or when special pretreatments were applied to a $\mathrm{RhCl}_{3} / \mathrm{Al}_{2} \mathrm{O}_{3}$ catalyst, oxo-selectivities of rhodium on alumina were also rather high $30 \% 9$.

\section{INTRODUCTION}

The reaction of $\mathrm{CO}$ and $\mathrm{H}_{2}$ over group VIII metals yields a wide range of products, such as alkanes, olefins and oxygenated nydrocarbons, the latter being the most interesting from an economical point of view. In recent investigations on supported rhodium catalysts a large percentage of oxygenated hydrocarbons has been reported (methanol, ethano], acetaldehyde and acetic acid) [1-7]. The activity and selectivity depended markedly on the support and promotors. Ichikawa [2-4] used various oxides to support metal carbonyl clusters, and found better selectivities towards oxygenates on basic oxides than on acidic oxides at atmospheric pressures or below. Rh/ZnO and Rh/MgO mainly produced methanol, while on $\mathrm{Rh} / \mathrm{La} 2 \mathrm{O}_{3}$ the main product was ethanol and $\mathrm{Rh} / \mathrm{SiO}_{2}$ only produced hydrocarbons. Bhas in and $\mathrm{O}^{\prime} \mathrm{Connor}$ observed that $\mathrm{Rh} / \mathrm{SiO}_{2}$ can aiso produce $\mathrm{C}_{2}$-oxygenates (ethanol, acetaldehyde and acetic acid) with selectivities up to $80 \%$ [8] at higher pressures ( $7 \mathrm{imPa}$, high pressure assists in shifting equilibria to the oxygenated products side). Since rhodium can produce $C_{2}$-oxygenates and platinum was reported to produce large amounts of methanol [9], it might be of interest to also investigate iridium in synthes is gas reaction at elevated pressures.

The mechanism for the formation of oxygenated products has not been elucidated so far. Recently Takeuchi and Katzer [10] and Tamaru et al. [11] demonstrated that the formation of methanol takes place by hydrogenation of nondissociatively adsorbed 
carbon monoxide. According to Watson and Somorjai [5-6] and Uriessen et a]. [12], the active sites for this reaction are metal ions. For $\mathrm{C}_{2}$-oxygenates different mechanisms have been proposed. Takeuchi and Katzer [13] suggested a complicated mechanism involving $C O$ insertion into adsorbed carbene species resulting in an adsorbed ketene or oxirene intermediate, thus indicating a common $C_{2}$-intermediate for $\mathrm{C}_{2}$-hydrocarbons and $\mathrm{C}_{2}$-oxygenates. The Schulz-Flory distribution of hydrocarbons and oxygenates supports this conclusion [14]. On the other hand Van den Berg et al. [1] and Tamaru et a1. [7] proposed a mechanism in which carbon monoxide insertion in $\mathrm{CH}_{\mathrm{x}}-\mathrm{Rh}^{\text {nt }}$ intermediates takes place, leading to $\mathrm{C}_{2}$-oxygenates. In this mechanism $\mathrm{C}_{1}$-hydrocarbons and $\mathrm{C}_{2}$-oxygenates have a common intermediate.

In this work, the catalytic behaviour in synthes is gas reaction at elevated pressure (4 MPa) of $\mathrm{Al}_{2} \mathrm{O}_{3}$ - and $\mathrm{SiO}_{2}$-supported rhodium and iridium catalysts has been studied. Special attention has been paid to the effect of chlorine remaining on the support after reduction of catalysts prepared with metal chloride precursors. This chlorine might influence the acidity of the catalyst and the amount of metal ions present in the reduced catalyst and therefore the catalytic behaviour.

\section{EXPERIMENTAL}

Catalyst preparation

Catalysts were prepared by the incipient wetness technique using $\mathrm{RhCl}_{3} \cdot \mathrm{xH}_{2} \mathrm{O}$, $\mathrm{Rh}\left(\mathrm{NO}_{3}\right)_{3} \cdot \times \mathrm{H}_{2} \mathrm{O}, \mathrm{H}_{2} \mathrm{IrCl}_{6} \cdot \mathrm{xH}_{2} \mathrm{O}, \mathrm{IrCl}_{3} \cdot \mathrm{HH}_{2} \mathrm{O}$ and $\mathrm{Ir}\left(\mathrm{NO}_{3}\right)_{3} \cdot \mathrm{xH}_{2} \mathrm{O}$ in aqueous solution. $\mathrm{SiO}_{2}$ from Grace (Type S.D. 2-324.382, surface area $290 \mathrm{~m}^{2} \mathrm{~g}^{-1}$, pore volume 1.2 $\mathrm{m} 7 \mathrm{~g}^{-1}$ ) and $\gamma-\mathrm{Al}_{2} \mathrm{O}_{3}$ from Ketjen (Type 000-1.5E, surface area $200 \mathrm{~m}^{2} \mathrm{~g}^{-1}$, pore volume $0.6 \mathrm{~m} 7 \mathrm{~g}^{-1}$ ) were used as support material. Impregnated catalysts were dried in air at $395 \mathrm{~K}$ for $16 \mathrm{~h}$ (heating rate $2 \mathrm{~K} \mathrm{~min}^{-1}$ ). Some catalysts were calcined in air at $723 \mathrm{~K}$ for $2 \mathrm{~h}$. In-situ reduction of the catalysts was carried out in a high pressure reactor in pure hydrogen at $0.1 \mathrm{MPa}$, using a temperature ramp of $5 \mathrm{~K} \mathrm{~min}^{-1}$ between $298 \mathrm{~K}$ and $623 \mathrm{~K}$, and holding that final temperature for $0.5 \mathrm{~h}$.

\section{Characterization techniques}

Reducibility of the catalysts was studied by temperature-programmed reduction (TPR) using the apparatus described extensively in ref. [15-16]. Reduction was done in a flow of $4 \% \mathrm{H}_{2}$ in Ar at a heating rate of $5 \mathrm{~K} \mathrm{~min}^{-1}$. Volumetric hydrogen chemisorption measurements were performed in a conventional glass system at $298 \mathrm{~K}$. After reduction in flowing purified hydrogen for $1 \mathrm{~h}$ at $673 \mathrm{~K}$ (heating rate $8 \mathrm{~K}$ $\min ^{-1}$ ), evacuation at $673 \mathrm{~K}$ for $0.5 \mathrm{~h}$, hydrogen admission at $473 \mathrm{~K}$ and cooling to room temperature, desorption isotherms were measured at room temperature. Following the method of Benson and Boudart [17] the total amount of chemisorbed $H$ atoms was obtained by extrapolating the linear higher pressure region $(0.02<\mathrm{P}<0.1 \mathrm{MPa})$ of the isotherm to zero pressure. 
The $\mathrm{CO}-\mathrm{H}_{2}$ reaction

Hydrogenation of carbon monoxide was carried out in a continuous flow stainlesssteel high pressure fixed-bed reactor. After in-silu reduction of the catalysts (see catalyst preparation), the reactor was cooled down to the reaction temperature and pressurized with $\mathrm{H}_{2}$ to the desired level. After stabilisation an additional $\mathrm{CO}$ flow was started. All catalysts were measured under the same reaction conditions (GHSV $=400011^{-1} h^{-1}, \mathrm{H}_{2} / \mathrm{CO}=3, \mathrm{P}=4 \mathrm{MPa}$ ). The reaction temperature was adjusted so that conversion of $C 0$ was around $2.0 \%$. The reactor effluent was analyzed using a column with Chromosorb $102(3 \mathrm{~m})$ and Porapack $\mathrm{T}(0.6 \mathrm{~m})$ in series operated at 423 K. Peak area integration was carried out with a Nelson Analytical Interface- IBM PC configuration.

\section{RESULTS ANU DISCUSSION}

\section{Characterization}

Hydrogen chemisorption measurements show that the silica-supported systems were well dispersed ( $H / \mathrm{Ir}=0.7$ for $2.5 \mathrm{wt} \%$ Ir and $H / R h=0.6$ for $1.5 \mathrm{wt} \%$. Rh), and that the a umina-supported systems were even highly dispersed ( $H / I r=1.7$ for 2.5 wt: Ir and $\mathrm{H} / \mathrm{Rh}=1.6$ for $1.5 \mathrm{wt} \% \mathrm{Rh}$ ) as shown in Tables 1 and 2 . Since most of the $\mathrm{H} / \mathrm{M}$ ratios exceed unity, it is impossible to calculate particle sizes and dispersions from chemisorption data and use these for calculating turnover frequencies. Therefore the $H / M$ values were only used to compare dispersions.

The TPR profiles of several cataiysts are presented in Figure 1. The reduction of the silica-supported catalysts occurred at significant higher temperatures than the reduction of the alumina-supported catalysts. Figure $1-c$ shows that when a
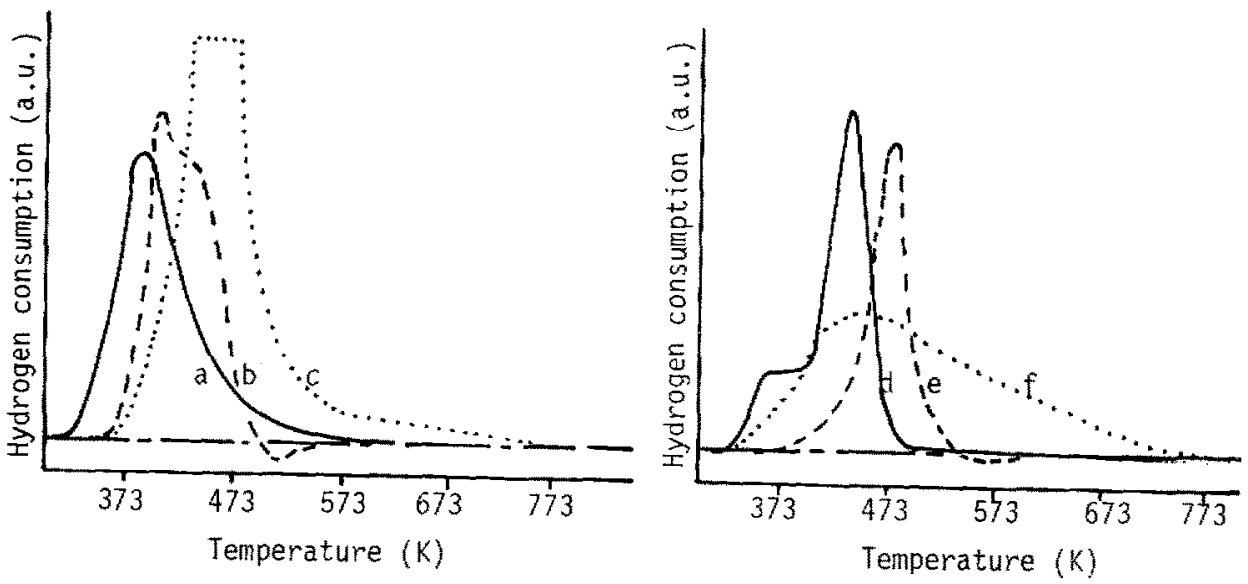

FIGURE 1 TPR profiles of impregnated catalysts dried at $393 \mathrm{~K}$ for $16 \mathrm{~h}$.

(a) $\mathrm{RhCl}_{3} / \mathrm{Al}_{2} \mathrm{O}_{3}$. (b) $\mathrm{IrCl}_{3} / \mathrm{Al}_{2} \mathrm{O}_{3}$. (c) $\mathrm{Rh}\left(\mathrm{NO}_{3}\right)_{3} / \mathrm{Al}_{2} \mathrm{O}_{3}$. (d) $\mathrm{RhCl}_{3} / \mathrm{SiO}_{2}$.

(e) $\mathrm{IrCl}_{3} / \mathrm{SiO}_{2}$. (f) $\mathrm{RhCl}_{3} / \mathrm{Al}_{2} \mathrm{O}_{3}$, calcined at $723 \mathrm{~K}, 2 \mathrm{~h}$. 
metal-nitrate precursor is used, the nitrate also reduces during the TPR-run, causing a huge hydrogen consumption. From these experiments it can be concluded that reduction at $623 \mathrm{~K}$ for $0.5 \mathrm{~h}$ in pure hydrogen will be sufficient to completely reduce the $\mathrm{Rh}$ and Ir catalysts, except may be for the calcined $\mathrm{RhCl}_{3} / \mathrm{Al}_{2} \mathrm{O}_{3}$ sample, for which reduction during TPR was complete only at $773 \mathrm{~K}$.

The $\mathrm{CO}-\mathrm{H}_{2}$ reaction

The catalytic properties of the various rhodium and iridium cataiysts in the synthesis gas reaction at standard conditions after $11 \mathrm{~h}$ time on stream are shown in Tables 1 and 2 . To keep the conversion below 5\% (differential conditions) and above $0.5 \%$ (necessary for accurate product analysis), catalysts were tested at different temperatures between 506 and $633 \mathrm{~K}$.

$\mathrm{RhCl}_{3} / \mathrm{Al}_{2} \mathrm{O}_{3}(1.5 \mathrm{wt} \% \mathrm{Rh})$, dried at $383 \mathrm{~K}$ for $16 \mathrm{~h}$ before in-situ reduction (Table 1-1) mainly produced methane, but also some methanol, dimethylether, ethanol, ethylmethylether, acetaldehyde and higher hydrocarbons. The total oxo-selectivity was $11 \%$. The ethers are believed to be formed by dehydratation of alcohols on acidic sites of the support. During the first hours of reaction a marked deactivation was observed, while after several hours all catalysts showed a small and constant relative deactivation $\left(0-2 \% \mathrm{~h}^{-1}\right)$. Total oxo-selectivity increased during the first hours and became constant after about $4 \mathrm{~h}$.

The $\mathrm{H}_{2} \mathrm{IrCl}_{6} / \mathrm{Al}_{2} \mathrm{O}_{3}$ catalyst $(2.5 \mathrm{wt} \% \mathrm{Ir}$, dried at $383 \mathrm{~K}$ before in-situ reduction, cf. Table 2-1) differed significantly from the rhodium catalyst. To obtain an activity similar to that of the rhodium catalyst the reaction temperature had to be increased to $593 \mathrm{~K}$. Using a value of $100 \mathrm{~kJ} \mathrm{~mol}^{-1}$ for the total activation energy [ 1 , $7,18]$, it can be calculated that $R h / \mathrm{Al}_{2} \mathrm{O}_{3}$ is 15 times more active than $\mathrm{Ir} / \mathrm{Al}_{2} \mathrm{O}_{3}$. This difference in activity was also reported by vannice [18], although he measured at atmospheric pressure. Ir $/ \mathrm{Al}_{2} \mathrm{O}_{3}$ al so showed a completely different selectivity. It oniy produced methane, methanol, dimethylether and higher hydrocarbons, while $\mathrm{C}_{2}-$ oxygenates were absent. The total oxo-selectivity was $11 \%$. The chain-growth probability was lound to be higher for the rhodium than for the iridium catalysts. The observed differences might be explained on the basis of the CO dissociation activity of transition metals [19]. Metals that easily dissociate CO catalyze hydrocarbon synthesis (i.e. Ru and $\mathrm{Fe}$ ), metals that adsorb $\mathrm{CO}$ non-dissociatively at room temperature catalyze synthesis of methanol (i.e. $\mathrm{Cu}, \mathrm{Pd}$. and Pt)[20]. Rh 1 ies between Ru and Pd and catalyzes the formation of both alcohols and hydrocarbons from $\mathrm{CO}$ and $\mathrm{H}_{2}$. Since it is capable of synthesizing both types of compounds, small effects can rarkedly alter its selectivity. There is no consensus in literature about iridium. Poutsma et a1. [20] reported non-dissociative adsorption of carbon monoxide on Ir, while van den Berg [21] reported dissociative adsorption. The results of the present study suggest that both $\mathrm{Rh}$ and Ir partly adsorb $\mathrm{CO}$ nondissociatively under reaction conditions and that Rh dissociates Co more easily than Ir. Vannice [18] suggested that the difference in activity between $R h$ and $\mathrm{Ir}$ is caused by a difference in heat 
TABLE 1

$\mathrm{CO}+\mathrm{H}_{2}$ reaction over various $1.5 \mathrm{wt} \%$ rhodium catalysts supported on $\mathrm{Al}_{2} \mathrm{O}_{3}$ and $\mathrm{SiO}_{2}{ }^{\mathrm{a}}$

\begin{tabular}{|c|c|c|c|c|c|c|c|c|}
\hline \multirow[t]{2}{*}{ no. } & \multirow[t]{2}{*}{ catalyst system ${ }^{b}$} & \multirow[t]{2}{*}{$H / R h$} & \multirow{2}{*}{$\begin{array}{l}\text { Acti- } \\
\text { vity }\end{array}$} & \multicolumn{5}{|c|}{ Selectivity $(\%)^{d}$} \\
\hline & & & & $\mathrm{CH}_{4}$ & $\mathrm{c}_{2}^{+} \mathrm{e}$ & $\begin{array}{l}\operatorname{tot}^{f} \\
\mathrm{C}_{2}-\mathrm{OH}\end{array}$ & $\begin{array}{l}\text { tot. } \\
\mathrm{C}_{2}-\mathrm{OH}\end{array}$ & $\begin{array}{l}\text { tot. } \\
\text { oxo }\end{array}$ \\
\hline 1 & $\mathrm{RhCl}_{3} / \mathrm{Al}_{2} \mathrm{O}_{3}{ }^{\mathrm{I}}, 1.8 \mathrm{~mol} / \mathrm{Cl}$ & 1.6 & 2.3 & 72.0 & 16.3 & 3.5 & 3.7 & 11.1 \\
\hline 2 & $\mathrm{RhCl}_{3} / \mathrm{SiO}_{2}, 0.1 \mathrm{~mol} \% \mathrm{Cl}$ & 0.6 & 0.6 & 48.0 & 11.3 & 26.7 & 14.0 & 40.7 \\
\hline 3 & $\mathrm{Rh}\left(\mathrm{NO}_{3}\right)_{3} / \mathrm{Al}_{2} \mathrm{O}_{3}$ & 1.3 & 0.6 & 45.4 & 14.4 & 27.5 & 11.1 & 38.6 \\
\hline 4 & $\mathrm{Rh}\left(\mathrm{NO}_{3}\right)_{3} / \mathrm{AT}_{2} \mathrm{O}_{3}$, calcined at $723 \mathrm{~K}$ & 1.6 & 1.8 & 50.8 & 11.9 & 19.5 & 14.1 & 35.3 \\
\hline 5 & $\begin{array}{l}\mathrm{Rh}\left(\mathrm{NO}_{3}\right)_{3} / \mathrm{Al}_{2} \mathrm{O}_{3}, \text { calcined at } 723 \mathrm{~K} \\
\mathrm{HCl} \text { treated, } 1.4 \mathrm{~mol} \% \mathrm{Cl}\end{array}$ & 1.4 & 0.9 & 61.3 & 24.9 & 9.3 & 0.0 & 11.7 \\
\hline 5 & $\mathrm{Rh}\left(\mathrm{NO}_{3}\right)_{3} / \mathrm{SiO}_{2}^{\mathrm{k}}$ & 0.4 & 1.1 & 44.2 & 7.1 & 35.6 & 13.1 & 48.6 \\
\hline 7 & $\mathrm{RnCl}_{3} / \mathrm{AT}_{2} \mathrm{O}_{3}, 4 \% \mathrm{H}_{2} \mathrm{O}$ & 1.6 & 2.6 & 63.9 & 4.1 & 14.7 & 14.8 & 29.5 \\
\hline 8 & $\mathrm{RhCl}_{3} / \mathrm{Al}_{2} \mathrm{O}_{3}, 1 \% \mathrm{H}_{2} \mathrm{O}^{l}, 1.8 \mathrm{~mol} \% \mathrm{Cl}$ & 1.6 & 1.5 & 72.8 & 15.3 & 4.9 & 4.9 & 11.9 \\
\hline 9 & $\begin{array}{l}\mathrm{RhCl}_{3} / \mathrm{Al}_{2} \mathrm{O}_{3}, 1 \% \mathrm{H}_{2} \mathrm{O} \text {, heating rate } \\
\text { during reduction } 30 \mathrm{Km} \mathrm{m}^{-1}, 1.5 \mathrm{mo}\end{array}$ & $\begin{array}{r}1.6 \\
115\end{array}$ & 2.2 & 60.1 & 7.3 & 16.0 & 12.6 & 30.8 \\
\hline U & $\begin{array}{l}\mathrm{RhCl}_{3} / \mathrm{Al}_{2} \mathrm{O}_{3}, \mathrm{H}_{2} \mathrm{O} \text { injection during } \\
\text { reduction, } 0.9 \text { mol } \mathrm{E} \mathrm{Cl}\end{array}$ & 1.3 & 4.0 & 57.0 & 5.8 & 9.5 & 17.0 & 29.6 \\
\hline 11 & $\mathrm{RhCl}_{3} / \mathrm{AT}_{2} \mathrm{O}_{3}$, calcined & 1.6 & 3.1 & 65.7 & 4.7 & 13.1 & 12.1 & 26.4 \\
\hline 12 & $\begin{array}{l}\mathrm{RhCl}_{3} / \mathrm{Al}_{2} \mathrm{O}_{3} \text {, calcined, reduction } \\
\text { at } 723 \mathrm{~K}\end{array}$ & 1.6 & 1.9 & 60.1 & 14.7 & 8.5 & 11.9 & 22.0 \\
\hline
\end{tabular}

(a) $T_{\text {react }}=523 \mathrm{~K}$, unless stated otherwise. (b) standard reduction (see experimenta1). (c) Activity in mole $c 0$ (mole $R h)^{-1} s^{-1}$. (d) calculated by carbon efficiency.

(e) $C_{2}{ }^{+}=C_{2}+C_{3}+C_{4}$ hydrocarbons. (f) tot. $C_{1}-O H=C_{1}-O H+C_{1}-0-C_{1}+1 / 3 C_{2}-0-C_{1}$.

(g) tot. $C_{2}-O H=C_{2}-O H+2 / 3 C_{2}-O-C_{1}$. (h) tot.oxo = tot. $C_{1}-O H+$ tot. $C_{2}-O H+C_{2}=0$.

(i) dried in-situ at $383 \mathrm{~K}, 16 \mathrm{~h}$ before reduction. (j) $T_{\text {react }}=623 \mathrm{~K}$. (k) $\mathrm{T}_{\text {react }}=$ $628 \times$. (1) $T_{\text {react }}=506 \mathrm{x}$.

of adsorption of Co (for Ir around $210 \mathrm{~kJ} \mathrm{~mol}^{-1}$, for Rh around $185 \mathrm{~kJ} \mathrm{~mol}^{-1}$ ).

The silica-supported $\mathrm{Rh}$ catalyst $\left(\mathrm{RhCT}_{3} / \mathrm{SiO}_{2}, 1.5 \mathrm{wt} \% \mathrm{Rh}\right.$, dried at $383 \mathrm{~K}$ for $16 \mathrm{~h}$ before in-situ reduction, Tabie 1-2) was less active than the $1.5 \mathrm{wt} \% \mathrm{Rh} / \mathrm{Al}_{2} \mathrm{O}_{3} \mathrm{Cata}-$ lyst, since the reaction temperature had to be increased up to $623 \mathrm{~K}$ to obtain a comparable conversion. In spite of this high temperature, its oxo-selectivity was much better, even though thermodynamically nigh temperature disfavours formation of oxygenates. Considerable amounts of methanol, dimethylether, ethanol and ethylmethylether were formed and total oxo-selectivity was $41 \%$.

The observed difference in oxo-selectivity between the alumina- and silica-supported $R h$ catalyst might be due to the difference in chlorine content of the reduced catalysts. XPS showed that after reduction of the dried $\mathrm{RhCl}_{3} / \mathrm{Al}_{2} \mathrm{O}_{3}$ and $\mathrm{RhCl}_{3} / \mathrm{SiO}_{2}$ heating rate $5 \mathrm{~K} \mathrm{~min}^{-1}, 0.5 \mathrm{~h}$ at $623 \mathrm{~K}$ ) there was a large difference in chlorine content. The surface of the reduced $\mathrm{Rh} / \mathrm{Al}_{2} \mathrm{O}_{3}$ contained 1.8 mol\% $\mathrm{Cl}$, whereas the 
TABLE 2

$\mathrm{CO}+\mathrm{H}_{2}$ reaction over various iridium catalysts supported on $\mathrm{Al}_{2} \mathrm{O}_{3}$ and $\mathrm{SiO}_{2}$.

\begin{tabular}{|c|c|c|c|c|c|c|c|c|}
\hline \multirow[t]{2}{*}{ no. } & \multirow[t]{2}{*}{ catalyst system $^{\mathrm{a}}$} & \multirow{2}{*}{$\begin{array}{l}\text { wt } \% \\
\text { Ir }\end{array}$} & \multirow[t]{2}{*}{$H / I r$} & \multirow{2}{*}{$\begin{array}{l}\text { Temp. } \\
(\mathrm{K})\end{array}$} & \multirow{2}{*}{$\begin{array}{l}\text { Acti- } \\
\text { vity }\end{array}$} & \multicolumn{3}{|c|}{ Selectivity $(\%)^{\mathrm{C}}$} \\
\hline & & & & & & $\mathrm{CH}_{4}$ & $\mathrm{c}_{2}^{+}$ & tot.oxo \\
\hline 1 & $\mathrm{H}_{2} \mathrm{IrCl}_{6} / \mathrm{AT}_{2} \mathrm{O}_{3}^{\mathrm{e}}$ & 2.5 & 1.7 & 593 & 2.5 & 73.2 & 15.6 & 11.2 \\
\hline 2 & $\begin{array}{l}\mathrm{H}_{2} \mathrm{IrCl}{ }_{6} / \mathrm{Al}_{2} \mathrm{O}_{3}, 4 \% \mathrm{H}_{2} \mathrm{O} \text {, heating } \\
\text { rate reduction } 30 \mathrm{k} \mathrm{min}^{-1}\end{array}$ & 2.5 & -- & 591 & 1.8 & 69.1 & 18.4 & 12.5 \\
\hline 3 & $\begin{array}{l}\mathrm{IrCl}_{3} / \mathrm{Al}_{2} \mathrm{O}_{3}, 4 \% \mathrm{H}_{2} \mathrm{O} \text {, heating } \\
\text { rate reduction } 30 \mathrm{~K} \mathrm{~min}^{-1}\end{array}$ & 2.6 & -- & 563 & 3.6 & 58.8 & 22.6 & 18.6 \\
\hline 4 & $\operatorname{Ir}\left(\mathrm{NO}_{3}\right)_{3} / \mathrm{Al}_{2} \mathrm{O}_{3}$ & 1.3 & 1.2 & 598 & 0.8 & 64.5 & 17.7 & 17.8 \\
\hline 5 & $\mathrm{IrCl}_{3} / \mathrm{SiO}_{2}$ & 2.5 & 0.7 & 633 & 1.0 & 72.6 & 16.3 & 11.1 \\
\hline 6 & $\operatorname{Ir}\left(\mathrm{NO}_{3}\right)_{3} / \mathrm{SiO}_{2}$ & 1.0 & 0.6 & 633 & 0.9 & 70.4 & 19.8 & 9.8 \\
\hline
\end{tabular}

(a) Reduced in pure $\mathrm{H}_{2}$, heating rate $5 \mathrm{~K} \mathrm{~min}^{-1}, 0.5 \mathrm{~h}$ at $623 \mathrm{~K}$ (b) Activity in mole converted $C 0$ (mole $I r)^{-1} s^{-1}$. (c) Calculated by carbon efficiency. (d) tot.oxo= $\mathrm{C}_{1}-\mathrm{OH}+\mathrm{C}_{1}-0-\mathrm{C}_{1}$. (e) dried in-situ at $383 \mathrm{~K}, 16 \mathrm{~h}$ before reduction.

surface of the reduced $\mathrm{Rh} / \mathrm{SiO}_{2}$ cuntained only $0.1 \mathrm{~mol} \% \mathrm{Cl}$. To further investigate this chlorine effect, $\mathrm{Al}_{2} \mathrm{O}_{3}$ was impregnated with $\mathrm{Rh}\left(\mathrm{NO}_{3}\right)_{3}$ (Table $1-3$ ). This catalyst showed a dispersion $(H / R h=1.3)$ comparable to that of $\mathrm{RhCl}_{3}$, a relatively low activity and a high oxo-selectivity (39\%). Calcination of the dried $\mathrm{Rh}\left(\mathrm{NO}_{3}\right)_{3} / \mathrm{Al}_{2} \mathrm{O}_{3}$ catalyst before reduction (Table 1-4) resulted in an increased activity without much loss of oxo-selectivity $(35 \%)$, while the selectivity to $\mathrm{C}_{2}$-oxygenates was increased. Thus, when a chlorine-free precursor is used, the oxo-selectivity can amount to about $40 \%$ on $\mathrm{Rh} / \mathrm{Al}_{2} \mathrm{O}_{3}$, significantly higher than the $10 \%$ obtained with dried $\mathrm{RhCl}_{3} / \mathrm{Al}_{2} \mathrm{O}_{3}$. Treating the calcined $\mathrm{Rh}\left(\mathrm{NO}_{3}\right)_{3} / \mathrm{Al}_{2} \mathrm{O}_{3}$ with gaseous $\mathrm{HCl}$ at $423 \mathrm{~K}$ in $\mathrm{N}_{2}$ atmosphere before reduction (Table 1-5) caused a dramatic decrease in the oxo-selectivity. Only small amounts of methanol, dimethylether and acetaldehyde were formed, ethanol and ethylmethylether were not formed at all and the total oxo-selectivity was only $12 \%$. Impregnation of $\mathrm{SiO}_{2}$ with $\mathrm{Rh}_{2}\left(\mathrm{NO}_{3}\right)_{3}$ (Table 1-6) also resulted in a catalyst with a high oxo-selectivity $(49 \%)$. Further investigations showed that the pretreatment procedure before synthesis gas reaction has an important influence on the oxo-selectivity (Table $1-7,8,9,10,11,12$ ). Normal reduction (heating rate $5 \mathrm{~K}$ $\mathrm{min}^{-1}$, final temperature $623 \mathrm{~K}$ ) of a rather wet $\mathrm{RhCl}_{3} / \mathrm{Al}_{2} \mathrm{O}_{3}$ (stored for half a jear and containing $4 \mathrm{wt} \% \mathrm{H}_{2} \mathrm{O}$ ) resulted in a high oxo-selectivity $(30 \%)$. $\mathrm{RhCl}_{3} / \mathrm{Al}_{2} \mathrm{O}_{3}$ only stored for one week $\left(1 \% \mathrm{H}_{2} 0\right)$ and reduced at $5 \mathrm{~K} \mathrm{~min}^{-1}$ showed a low oxo-selectivity $(12 \%)$, while reduction of this catalyst at $30 \mathrm{~K} \mathrm{~min}^{-1}$ improved the oxo-selectivity to $31 \%$. Reduction of a dried $\mathrm{RhCl}_{3} / \mathrm{Al}_{2} \mathrm{O}_{3}$ in the presence of water vapour (water injection in the reactor during reduction) also increased the oxo-selectivity ( $30 \%$, Table 1-10). These results indicate that the water vapour pressure during the reduction of $\mathrm{RhCl}_{3} / \mathrm{Al}_{2} \mathrm{O}_{3}$ is an important factor. The observed differences can not be explained by differences in metal dispersions as can be seen in Table 1 . RhC ${ }_{3} / \mathrm{Al}_{2} \mathrm{O}_{3}$, 
calcined at $723 \mathrm{~K}$ for $2 \mathrm{~h}$ followed by reduction at $623 \mathrm{~K}$ (Table $1-11$ ) had a relatively high oxo-selectivity $\left(26^{\%}\right)$, reduction of this catalyst at $723 \mathrm{k}$ showed a somewhat lower oxo-selectivity caused by a decreased $\mathrm{C}_{1}-\mathrm{OH}$ selectivity (Table 1-12).

For the alumina-supported iridium catalysts the differences in oxo-selectivity were smaller. Reduction of dried $\mathrm{H}_{2} \operatorname{IrCl}_{6} / \mathrm{Al}{ }_{2} \mathrm{O}_{3}$ at $5 \mathrm{Kmin}^{-1}$, final temperature 623 $\mathrm{K}$ (Table 2-1) resulted in $11 \%$ oxo-selectivity. $\operatorname{Ir}\left(\mathrm{NO}_{3}\right)_{3} / \mathrm{Al}_{2} \mathrm{O}_{3}$ (Table 2-4) showed an oxo-selectivity of $18 \%$. Thus, also for iridium the chlorine-free precursor gives a higher oxo-selectivity. Reduction of the chlorine containing iridium catalysts in the presence of water vapour resulted in oxo-selectivities of $13 \%$ and $19 \%$ (Table $2-2,3)$. However, on $\mathrm{S}_{2} \mathrm{O}_{2}$ the oxo-selectivities of iridium catalysts were 10 w $(10 \%)$.

We think that the observed chlorine effect can be understood in the following way. During the reduction of the $\mathrm{RhCl}_{3} / \mathrm{Al}_{2} \mathrm{O}_{3}$ catalyst, the following reactions take place:

$$
\begin{array}{lll}
\mathrm{RhCl}_{3}+1.5 \mathrm{H}_{2} & \leftrightarrow--\mathrm{Rh}+3 \mathrm{HCl} \\
2 \mathrm{Al}-\mathrm{OH} & \leftrightarrow-\mathrm{Al}-\mathrm{O}+\mathrm{Al}-0+\mathrm{H}_{2} \mathrm{O} \\
\mathrm{Al}-\mathrm{D}+\mathrm{Al}-\mathrm{O}+\mathrm{HCl} & \leftrightarrow-\rightarrow \mathrm{Al}-\mathrm{Cl}+\mathrm{Al}-\mathrm{OH}
\end{array}
$$

When the reduction of RhCl $\mathrm{K}_{3}$ (1) and the dehydroxylation of alumina surface 0H-groups (2) take place at the same time, the chloride can be trapped by the alumina next to the reduced rhodium particles (3). During the reduction of the metal chloride a high water vapour pressure shifts the second equilibrium to the left and thus prevents the trapping of the chlorine. On $\mathrm{SiO}_{2}$ almost no chlorine was trapped during the reduction of the metal chlorides as shown by the XPS measurements. Therefore oxoselectivities were high. Calcination of the catalyst before reduction probably removed the chlorine and therefore increased the oxo-selectivity.

Several explanations might be given for the observed influence of chlorine on the oxo-selectivity:

- Secondary reactions might play an important role. Once oxygenates are formed, they might decompose to hydrocarbons on acidic sites of the alumina (thermodynamically hydrocarbons are favoured over oxygenates). Chlorine increases this acidity and thus favours the decomposition of oxygenates.

- The different pretreatment procedures and the presence of chlorine might cause different amounts of metal ions in the reduced catalyst and thus cause different selectivities to methanol (which is supposed to be formed on metal ions [5-6,12]). - $C_{2}$-oxygenates might be formed by intermediates that have a structure like acetate ions $\left(\mathrm{CH}_{3} \mathrm{C}-\mathrm{O}-\mathrm{O}-\mathrm{M}\right)$ with one oxygen atom of the support [7]. The chlorine remai-

ning on the support next to the rhodium particles after reduction of the $\mathrm{RhCl}_{3}$ may inhibit the formation of these intermediates.

In summary, Rh/Al $2_{3}$ was more active and had a higher chain-growth probability than $\operatorname{Ir} / \mathrm{Al}_{2} \mathrm{O}_{3}$. Rh catalysts produced methanol, dimethylether, ethanol, ethylmethylether, acetaldehyde and hydrocarbons, while Ir catalysts produced only methanol, 
dimethylether and hydrocarbons. Chlorine, trapped by vacancies on the alumina surface, formed by dehydroxylation of OH-groups, disfavoured the formation of oxygenates in the hydrogenation of $\mathrm{CO} . \mathrm{On} \mathrm{SiO}_{2}$ this effect was not observed. High water vapour pressure during the reduction of the metal chloride on alumina prevented the trapping of chlorine and high oxo-selectivities were measured in that case. Calcination of the $\mathrm{RhCl}_{3} / \mathrm{Al}_{2} \mathrm{O}_{3}$ system caused removal of the chlorine, resulting in high oxo-selectivities.

The negative influence of chlorine on the activity is not completely understood. Possibly chlorine enhances the formation of coke, or alternatively it covers part of the active metal area.

Although the influences of several supports [2-6,9] and promotors [3] have been described in literature, the here observed effect has not been mentioned yet. Our study demonstrates that, in comparing the catalytic activity and selectivity of metal catalysts for $\mathrm{C} 0$ hydrogenation the influence of the metal salt precursor and the pretreatments should be taken into account.

\section{ACKNOWLEDGEMENTS}

This research was supported by the Netherlands Foundation for Chemical Research (SON) with financial aid from the Netherlands Organization for the Advancement of Pure Researck (ZWO). The authors thank Or. J.W. Niemantsverdriet for recording the XPS spectra.

\section{REFERENCES}

1 F.G.A. van den Berg, J.H.E. Glezer and W.M.H. Sachtler, J. Catal., 93 (1985) 340.

2 M. Ichikawa, Bu11. Chem. Soc. Jap., 51 (1978) 2268.

3 M. Ichikawa, Bul1. Chell. Soc. Jap., 51 (1978) 2273.

4 M. Ichikawa, J.C.S. Chem. Comm., (1978) 566.

5 P.R. Watson and G.A. Somorjai, J. Catal., 72 (1981) 347.

6 P.R. Watson and G.A. Somorjai, J. Catal., 74 (1982) 282.

7 H. Orita, S. Naito and K. Tamaru, J. Catal., 90 (1984) 183.

8 M.M. Bhas in and G.L. 0'Connor, Belgian Pattent 824822, to Union Carbide Corp., 1975.

9 M. Ichikawa and K. Shikakura, Proc. 7th Int. Congr. Catal., Tokyo (1980) 925.

10 A. Takeuchi and J.R. Katzer, J. Phys. Chem., 85 (1981) 937.

11 Y. Kobori, H. Yamasaki, S. Naito, T. Onishi and K. Tamaru, Chem. Lett. (1983) 553.

12 J.M. Driessen, E.K. Poels, J.P. Hindermann and V. Ponec, J. Catal., 82 (1983) 20.

13 A. Takeuchi and J.R. Katzer, J. Phys. Chem., 86 (1983) 2438.

14 A. Takeuchi, J.R. Katzer and R.W. Crecely, J. Catal., 82 (1983) 479.

15 H. Boer, W.J. Boersma and N. Wagstaff, Rev. Sci. Instr., 53 (1982) 439.

16 T. Huizinga, J. van Grondelle and R. Prins, Appi. Catal., 10 (1984) 199.

17 J.E. Benson and M. Boudart, J. Catal., 4 (1965) 704.

18 M.A. Vannice, J. Catal., 37 (1975) 462.

19 J.R. Katzer, A.W. Sleight, P. Gajardo, J.B. Michel, E.F. Gleason and S. McMill an Far. Disc. Chem. Soc., 72 (1981) 121.

20 L. Poutsma, L.F. Elek, P.A. Ibarbia, A.P. Risch and J.A. Rabo, J. Catal., 52 (1978) 157.

21 F.G.A. van den Berg, Thesis, Leiden University (1983). 